Vol. 7 No. 1 Bulan Januari Tahun 2016 Hal 55-66

p-ISSN : 2088-6845 e-ISSN : 2442-8604

\title{
WORKING CAPITAL DAN LIKUIDITAS: STUDI PADA KOPERASI KOSTRANDA BATAN DI JAKARTA SELATAN
}

\author{
Leonardo Jhones Pattipeilohy, Pitri Yandri \\ STIE Ahmad Dahlan Jakarta \\ E-mail:leonardojhones13@yahoo.com;p.yandri@gmail.com
}

\begin{abstract}
The purpose of this study is to analyze the effect of the liquidity on working capital in the Cooperative Kostandra Batan. The measurement standard refers to the Minister of Cooperatives and Small and Medium Enterprises of the Republic of Indonesia No. 06/Per/M.KUKM /V/2006 on guidelines on the assessment of cooperative achievement. The values tested in this study using regression analysis. The results showed an increase in working capital amounted to $1 \%$ will increase the liquidity of $37.3 \%$. Working capital is able to explain the variation of liquidity amounting to $68.9 \%$.
\end{abstract}

Keywords : Cooperative, Effect Liquidity, Working Capital

\begin{abstract}
Abstrak
Tujuan penelitian ini adalah menganalisis pengaruh modal kerja terhadap likuiditas pada Koperasi Kostandra Batan dengan standar likuiditas mengacu pada Peraturan Menteri Negara Koperasi dan Usaha Kecil dan Menengah Republik Indonesia No. 06/Per/M.KUKM/V/2006 tentang pedoman penilaian koperasi berprestasi. Nilai-nilai yang diuji dalam penelitian ini menggunakan analisis regresi. Hasil penelitian menunjukkan, peningkatan modal kerja sebesar 1\% akan meningkatkan likuiditas sebesar 37.3\%. Modal kerja mampu menjelaskan variasi likuiditas sebesar sebesar $68.9 \%$.
\end{abstract}

Kata kunci : Koperasi, Likuiditas, Modal Kerja 
Ekonomika-Bisnis,Vol. 7 No. 1 Bulan Januari Tahun 2016 Hal 55-66

Indonesia memiliki tiga pelaku kekuatan ekonomi untuk melaksanakan berbagai kegiatan dalam tatanan kehidupan perekonomian. Ketiga pela$\mathrm{ku}$ tersebut adalah negara, swasta dan koperasi. Koperasi adalah badan usaha yang beranggotakan orang-seorang atau badan hukum koperasi dengan melandaskan kegiatannya berdasarkan prinsip koperasi sekaligus sebagai gerakan ekonomi rakyat yang berdasar atas asas kekeluargaan. Persaingan usaha yang terjadi menuntut setiap perusahaan termasuk juga koperasi agar lebih siap dan mampu menjalan-kan usahanya.

Hal ini dimaksudkan agar koperasi dapat menjaga kelangsungan hidupnya dan mampu bertahan dalam dunia persaingan tersebut. Tidak sedikit persahaan yang kalah dalam menjalankan usahanya disebabkan karena tidak mampu mengikuti dinamika persaingan yang terjadi sehingga menyebabkan kerugian dan kebangkrutan. Hanya koperasi yang siap dalam mengelola manajemen perusahaan dengan baik yang mampu bersaing dan mempertahankan kelangsungan usaha.

Pada prakteknya, koperasi harus dikelola dengan manajemen yang baik. Manajemen koperasi harus mempunyai perencanaan yang matang dan kesiapan dalam menghadapi persaingan yang terjadi, karena hambatan yang dihadapi dalam menjalankan kegiatan usaha tidak hanya datang dari luar saja melainkan juga dari dalam perusahaan.

Oleh karena itu manajemen koperasi harus mampu mengatasi persaingan yang terjadi terutama dari dalam koperasi itu sendiri. Banyak cara yang dapat dilakukan oleh koperasi dalam melakukan kesiapan itu, salah satunya dalam hal modal kerja yang dimiliki dan dikelola oleh koperasi. Modal kerja harus dibuatkan perencanaan guna untuk menjalankan aktifitas operasionalnya. Tidak hanya perencanaan, tetapi modal kerja juga harus dikelola dengan baik agar dana (modal) yang tersedia dapat dikelola secara efektif dan efisien.

Kelangsungan hidup koperasi dapat dijamin dari pengelolaan modal kerja yang baik agar dapat menghasilkan laba bagi perusahaan untuk memenuhi kebutuhan perusahaan baik jangka pendek maupun kebutuhan jangka panjang. Kasmir (2015) mengemukakan bahwa modal kerja merupakan dana yang digunakan untuk membiayai kegiatan operasional perusahaan, terutama yang memiliki jangka waktu pendek. Sebagai modal kerja diartikan seluruh aktiva lancar atau setelah dikurangi dengan utang lancar.

Pendapat lain, Kolb (2003) dalam Kasmir (2015) misalnya menyatakan bahwa "working capital is the investmen of the firm in short-term or current assets, which includes cash, marketable securities, account receviable, short-term notes receivales, inventories, and in some firms, expense prepayments", (modal kerja adalah investasi perusahaan dalam aktiva jangka pendek atau lancar, termasuk di dalamnya kas, sekuritas, piutang, persediaan, dan dalam beberapa perusahaan, biaya dibayar dimuka).

Modal kerja sangat penting bagi koperasi dalam menentukan tingkat likuiditas koperasi. Modal kerja dapat terlihat dari bagaimana pe-rusahaan tersebut menjaga keseimbangan jumlah aktiva lancar dan jumlah hutang lancar agar dapat dipergunakan untuk menunjang operasional koperasi. 
Working Capital dan Likuiditas...(Leonardo Jhones Pattipeilohy, Pitri Yandri)

Sepanjang keseimbangan tersebut tercapai, maka modal kerja koperasi tersebut dapat dikatakan baik dalam menentukan tingkat likuiditas koperasi.

Kebutuhan modal kerja harus cukup jumlahnya karena dengan adanya modal kerja yang cukup akan memungkinkan bagi koperasi untuk terus beroperasi semaksimal mungkin. Namun sebaliknya, dengan modal kerja yang berlebihan menunjukan adanya dana yang tidak produktif dan akan menimbulkan kerugian bagi sebuah entitas bisnis, termasuk kop-erasi karena akan kehilangan kesem-patan untuk memperoleh keuntungan yang lebih besar lagi.

Begitu pula jika kekurangan modal kerja dapat mengganggu jalannya operasional perusahaan (koperasi), sehingga menghampat pencapaian tujuan koperasi. Agar tidak kekurangan atau kelebihan maka manajemen harus mampu mengelola keuangan untuk menentukan komposisi dari masing-masing komponen atau unsur-unsur modal kerja yang sesuai dengan kebutuhan kegiatan koperasi.

Modal kerja dibutuhkan oleh setiap badan usaha atau manajemen dalam hal mempertimbangkan dan menentukan suatu kebijakan dalam koperasi maka manajemen mempunyai kewajiban-kewajiban untuk memperhatikan pengelolaan dan penggunaan modal kerja agar dapat dipergunakan sesuai dengan kebutuhan operasional koperasi. Begitu juga dengan manajemen koperasi yang berupaya untuk mengelola modal kerja yang dimiliki dengan semaksimal mungkin sehingga koperasi dapat berjalan dengan efektif untuk mencapai tujuan koperasi dan dapat menghasilkan laba yang diinginkan.
Modal kerja digunakan untuk pembiayaan jangka pendek, seperti pembelian bahan baku, membayar gaji dan upah, dan biaya operasional lainnya yang kurang dari satu tahun. Hal ini berlaku lebih penting lagi bagi koperasi yang ingin memenuhi tingkat likuiditasnya karena manajemen modal kerja yang baik akan menghasilkan laba perusahaan yang tinggi sehingga mampu memenuhi kewajiban perusahaan, terutama dalam jangka pendek (likuiditas).

Karena itu, studi Quayyum (2011) dan (2012) membuktikan bahwa tingkat signifikasi hubungan antara profitabilitas dan berbagai indeks likuiditas serta komponen modal kerja saling berkorelasi satu sama lain secara signifikan.

Oleh sebab itu, modal kerja digunakan sebagai dana untuk kegiatan operasional koperasi sehingga koperasi memiliki pendapatan pada kegiatan usahanya. Hasil kegiatan usaha koperasi akan masuk sebagai harta pada aktiva, hal tersebut akan berpengaruh terhadap tingkat likuiditas koperasi.

Berdasarkan konteks manajemen keuangan koperasi di Indonesia, sesuai dengan Peraturan Menteri No. 06/Per/M.KUKM/2006 tentang penilaian prestasi koperasi atas koperasi award, di mana likuiditas termasuk dalam salah satu aspek penilaian tersebut dengan standar likuid berada pada 175\%-275\%. likuiditas dapat diukur dengan rasio lancar (current ratio), dimana jumlah aktiva lancar tergantung pada kebijakan modal kerja koperasi dan jumlah utang lancar tergantung pada kebijakan pembiayaan 
Ekonomika-Bisnis,Vol. 7 No. 1 Bulan Januari Tahun 2016 Hal 55-66

Dalam hal aktiva lancar yang
tinggi atau tertentu dengan pembiayaan
yang mengarah pada pembiayaan
jangka panjang Setiap badan usaha
termasuk koperasi selalu membutuh-
kan modal kerja untuk membelanjai
operasinya sehari-hari. Misalkan untuk
membeli persekot pembelian bahan
mentah, membayar upah karyawan, gaji
pegawai dan lain sebagainya. Dimana
uang atau dana yang telah dikeluarkan
itu diharapkan akan dapat kembali lagi
masuk dalam koperasi dalam waktu
yang pendek melalui hasil produksinya.

Menurut Kinerja Keuangan

Koperasi Dinas Perindustrian,

Perdagangan dan Koperasi, tingkat

likuiditas koperasi digolongkan menjadi empat kriteria: (1) tidak likuid; (2) cukup likuid; (3) likuid dan (4) sangat likuid. Ketika nilai persentase lebih besar dari 300\% maka koperasi dikatakan over likuid hal ini menunjukan jumlah harta lancar sangat mencukupi untuk menjamin utang lancar yang dimiliki oleh koperasi, kondisi seperti ini dapat dikatakan tidak baik karena harta lancar yang dimiliki masih bisa dikelola sehingga dapat menghasilkan keuntungan baru bagi koperasi.

Ketika nilai persentase diantara 150\%-300\% hal ini menunjukan tingkat likuiditas yang baik bagi koperasi, karena jumlah harta lancar yang dimiliki koperasi mencukupi untuk menjamin utang lancar yang dimiliki. Ketika nilai persentase diantara $100 \%-150 \%$ hal ini menunjukan tingkat likuiditas yang cukup bagi koperasi, namun jumlah harta lancar yang dimiliki terlalu sedikit untuk menutupi jumlah utang lancar. Koperasi dikatakan tidak likuid ketika memiliki persentase di bawah $100 \%$, hal ini menunjukan bahwa koperasi tidak memiliki harta lancar yang mencukupi untuk menutupi utang lancar yang dimiliki.

Studi sebelumnya yang telah meneliti modal kerja telah banyak dilakukan, tetapi lokus penelitian lebih kepada kaitan modal kerja dengan profitabilitas. Hal tersebut terlacak misalnya dalam studi yang dilakukan oleh Makori dan Jagongo (2013); Nopiana, Herawati dan Sulindawati (2015); dan Hadinata dan Wirawati (2016). Namun demikian, sejumlah studi tersebut belum menaruh perhatiannya pada likuiditas. Atas alasan itu, penelitian ini bertujuan mengkaji pengaruh modal kerja terhadap likuiditas pada Koperasi Kostranda Batan di Jakarta Selatan.

Koperasi Kostandra Batan" merupakan badan usaha yang bergerak di bidang usaha simpan pinjam dan lainnya. Koperasi Kostandra ini telah berbadan hukum dengan akte Pendirian No. 2521/B.H/I Tanggal 22 Juni 1990 yang ditandatangani oleh Ir. Yayan S. Danuatmaja. Sesuai dalam pasal 1 UU. No. 20/2008 tentang perkoperasian yang tercantum dalam Bab I Anggaran Dasar di Koperasi Kostandra "Batan" bahwa koperasi ini berlandaskan pada Pancasila dan UUD 1945 serta berasas atas asas kekeluargaan.

\section{Metode Penelitian}

Data-data yang dikompilasi dalam penelitian ini adalah data sekunder. Kompilasi data sekunder dilakukan dengan cara pencatatan dan pengkategorian data. Rincian data yang dikumpulakan adalah modal kerja dan likuiditas. Secara teoritik, modal kerja dibagi menjadi dua yaitu Gross Working Capital dan Net working capital. Pada penelitian ini, modal kerja diproxi dari modal kerja bersih 
Working Capital dan Likuiditas...(Leonardo Jhones Pattipeilohy, Pitri Yandri)

(net working capital). Sementara, likuditas diproxi dari current ratio.

Berikut ini adalah formulasi matematika untuk menghitung modal kerja bersih dan current ratio tersebut.

Net working capital =Aktiva Lancar - Hutang Lancar

Current Ratio $=\frac{\text { Aktiva Lancar }}{\text { Hutang Lancar }} \times 100 \%$

Periode laporan keuangan yang diamati adalah tahun 2010-2014. Karena jumlah series data hanya 5 (lima) tahun, maka dalam rangka analsis regresi dilakukan interpolasi data. Data tahunan akan dipecah menjadi data kuartal dengan menggunakan perangkat lunak e-views versi 6. Hasil interpolasi data sebagaimana terlampir dalam artikel ini.

Untuk menduga pengaruh modal kerja terhadap likuiditas digunakan model regresi dengan persamaan sebagai berikut.

$\mathrm{Yt}=\alpha+\beta(\ln \mathrm{Xt})+\varepsilon$

Keterangan:

Y: likuiditas

$\ln \mathrm{X}$ : logaritma natural modal kerja

$\alpha$ : intersep (nilai likuiditas bila modal kerja $=0$ )

$\beta$ : kemiringan garis atau nilai rata-rata pada likuiditas untuk setiap dinamika (naik atau turun) pada modal kerja $\varepsilon$ : error

Terdapat perbedaan satuan data pada variabel modal kerja dan likuiditas. Satuan data pada variabel modal kerja adalah dalam nominal rupiah. Sementara satuan data pada variabel likuiditas adalah dalam persen. Dalam prosedur standar statistika, perbedaan satuan data ini harus diseragamkan. Karena itu lah logaritma natural digunakan untuk mentransformasi variabel modal kerja ke dalam bentuk persen. Sehingga dengan cara itu, satuan data telah seragam.

Pengolahan data menggunakan perangkat lunak SPSS versi 20. Hipotesis penelitian adalah diduga bahwa modal kerja berpengaruh positif signifikan terhadap tingkat likuiditas Koperasi Kostandra. Hipotesis statistik dirumuskan sebagai berikut:

Ho : $\rho=0$

Modal kerja berpengaruh positif signifikan terhadap tingkat likuiditas pada Koperasi Kostandra Batan

Ha $: \rho \neq 0$

Modal kerja tidak berpengaruh positif signifikan terhadap tingkat likuiditas pada Koperasi Kostandra Batan

Untuk mengetahui ada atau tidaknya pengaruh yang signifikan antara modal kerja (X) terhadap likuiditas (Y) maka dilakukan uji t. Formula umum uji $\mathrm{t}$ mengacu pada Juanda (2009: 29):

$$
t=\frac{\hat{\beta}-\beta}{S \hat{\beta}}
$$

Di mana:

$\widehat{\beta} \quad$ :Beta dugaan

$\beta$ :(yaitu nilai Likuiditas bila modal kerja $=0)$

$S \hat{\beta}:$ Standar Defiasi dari (beta dugaan) 
Ekonomika-Bisnis,Vol. 7 No. 1 Bulan Januari Tahun 2016 Hal 55-66

\section{Hasil Penelitian dan Pembahasan}

Secara deskriptif, aktiva lancar dan hutang lancar yang dimiliki oleh Koperasi Kostandra mengalami fluktuasi selama 5 (lima) tahun yaitu Peningkatan aktiva lancar terjadi pada tahun 2011, 2013 dan 2014 yaitu sebesar $12,8 \%, 18,6 \%$ dan $6,1 \%$ sedangkan penurunan persentase aktiva lancar terjadi pada tahun 2012 sebesar $18,71 \%$ yang disebabkan oleh beberapa faktor. Informasi yang diperoleh, salah satu penyebabnya adalah penurunan pada piutang atau kredit Bank Bukopin sebesar Rp. 935.283.334,6 pada aktiva lancar.
Peningkatan dan penurunan persentase pada aktiva lacar berbanding lurus dengan persentase hutang lancar yang dimiliki. Pada tabel 1 terlihat peningkatan persentase hutang lancar terjadi pada tahun 2011, 2013 dan 2014 yaitu sebesar $12,4 \%, 22 \%$ dan $2 \%$ sedangkan penurunan persentase hutang lancar terjadi pada tahun 2012 sebesar 27,09\%. Faktor utama penurunan ini disebabkan oleh penurunan hutang pada Bank Bukopin sebesar Rp. 855.714.541,6 pada hutang lancar. Dengan menggunakan formula current ratio, diperoleh informasi tingkat current ratio pada Koperasi Konstranda Batan.

Tabel 1. Current ratio Koperasi Kostranda Batan

\begin{tabular}{cccr}
\hline Tahun & $\begin{array}{c}\text { Aktiva Lancar } \\
(\mathrm{Rp})\end{array}$ & $\begin{array}{c}\text { Pasiva Lancar } \\
(\mathrm{Rp})\end{array}$ & $\begin{array}{c}\text { Current ratio } \\
(\%)\end{array}$ \\
\hline 2010 & $5,965,643,914$ & $4,616,345,169$ & 129.23 \\
2011 & $6,729,271,239$ & $5,189,263,376$ & 129.68 \\
2012 & $5,470,495,971$ & $3,783,525,081$ & 144.59 \\
2013 & $6,485,443,408$ & $4,618,842,108$ & 140.41 \\
2014 & $6,886,792,790$ & $4,710,928,423$ & 146.19 \\
\hline
\end{tabular}

Sumber: data diolah, 2016

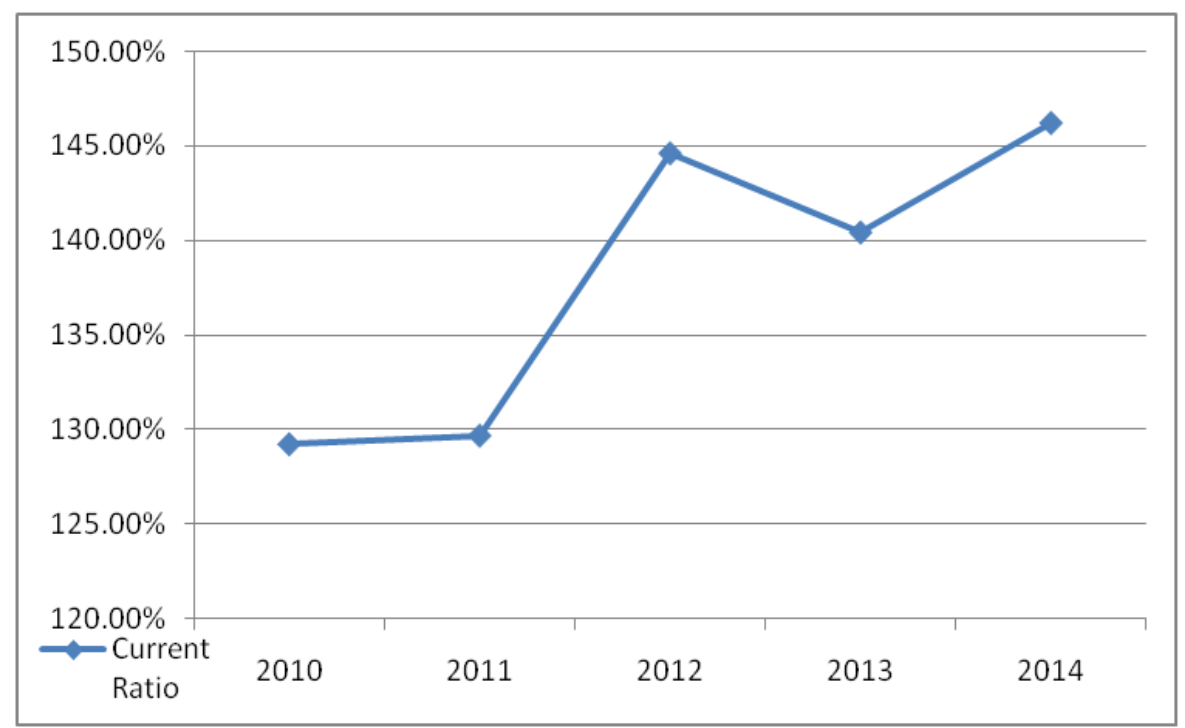

Sumber : data diolah

Gambar 1. Dinamika Current ratio Koperasi Konstranda Batan 2010-2014 
Working Capital dan Likuiditas...(Leonardo Jhones Pattipeilohy, Pitri Yandri)

\begin{tabular}{lll}
\hline Berdasarkan tabel 1 dan gambar & UKM Republik Indonesia No. \\
1, tergambar bahwa pada tahun 2010 & 06/Per/M.KUKM/V/2006 bahwa cur- \\
current ratio sebesar 129.23\% yang & rent ratio 200\%<250\%= kurang sehat, \\
artinya setiap Rp.1.- kewajiban & akan tetapi koperasi masih mempunyai \\
koperasi dijamin dengan Rp.1,29,- ak- & kemampuan membayar kewajiban fi- \\
tiva lancar. Hal ini menggambarkan & nansialnya karena jumlah aktiva lancar \\
bahwa keuangan koperasi masih kurang & lebih besar dari jumlah hutang \\
memuaskan karena masih dibawah & lancarnya.
\end{tabular}
standar yaitu 2:1. Tetapi rasio likuiditas $129.23 \%$ tersebut masih berada di atas $100 \%$, dimana jumlah aktiva lancar pada tahun 2010 masih lebih besar dari hutang lancar yang dimiliki, sehingga koperasi masih mempunyai kemampuan untuk mem-bayar kewajiban jangka pendeknya. Pada tahun 2011 current ratio tidak banyak mengalami perubahan sehingga kemampuan aktiva lancar untuk menanggung hutang lancar sama seperti pada tahun sebelumnya yaitu sebesar $129 \%$ atau $1.29: 1$.

Pada tahun 2012 terjadi peningkatan jumlah likuiditas sebesar $14.91 \%$ yang semula sebesar $129.68 \%$ meningkat menjadi $144.59 \%$ yang artinya kemampuan hutang lancar untuk menjamin hutang lancarnya meningkat menjadi 1.44 : 1 namun kondisi ini masih dikatakan lemah karena belum mencapai standar yang ditetapkan.

Pada tahun 2013 likuiditas mengalami penurunan sebesar $4.18 \%$ menjadi $140.41 \%$, walaupun mengalami penurunan pada current ratio di tahun 2013 tetapi masih mempunyai kemampuan menjamin kewajiban lancarnya karena jumlah aktivanya masih lebih besar dari pada hutang lancarnya. Pada tahun 2014 current ratio kembali mengalami peningkatan sebesar $5.78 \%$; yang semula $140.41 \%$ menjadi $146.19 \%$. Hal ini masih menunjukan bahwa likuiditas Koperasi Kostandra masih kurang memuaskan karena berada di bawah rata-rata standar Peraturan Menteri Negara Koperasi dan

Sementara pada komponen modal kerja (net working capital) dapat dinyatakan sehat karena tidak pernah mengalami penurunan jumlah modal kerja dan selalu mengalami kenaikan setiap tahunnya, dimana pada tahun 2011 peningkatan jumlah modal kerja sebesar Rp.190,709,117.52 yang disebabkan oleh bertambahnya jumlah piutang pada Bank Bukopin serta piutang pada Bank Jabar yang meningkat dari tahun 2010. Pada tahun 2012 modal kerja yang dimiliki Koperasi Kostandra sebesar Rp. $1,686,970,889.56$ atau meningkat Rp.146,963,027.20 dari tahun sebelumnya, pada tahun ini jumlah aktiva lancar dan hutang lancar yang dimiliki Koperasi Kostandra mengalami penurunan yang di-sebabkan oleh berkurangnya jumlah piutang atau kredit pada Bank Bukopin pada aktiva lancar dan berkurangnya hutang pada Bank Bukopin pada hutang lancar.

Pada tahun 2013 modal kerja yang dimiliki oleh Koperasi Kostandra meningkat sebesar Rp 179,630,410.30 dari tahun sebelumnya, dan pada tahun 2014 modal kerja yang dimiliki oleh Koperasi Kostandra mengalami peningkatan tertinggi selama 5 (lima) tahun terakhir yaitu sebesar Rp.289,263,066.90 dari tahun sebelumnya, dimana modal kerja yang dimiliki pada tahun ini sebesar Rp.2,175,864,366.76 sehingga dapat disimpulkan modal kerja tertinggi terjadi pada tahun 2014 yaitu sebesar Rp 
2,175,864,366.76 dan modal kerja terendah terjadi pada tahun 2010 yaitu sebesar Rp.1,349,298,744.84. Tabel 2 d bawah ini menunjukkan dinamika modal kerja bersih di Koperasi
Kostranda Batan pada tahun 20102014.

Tabel 2. Modal Kerja

\begin{tabular}{cccc}
\hline \multirow{2}{*}{ Tahun } & Net working capital & \multicolumn{2}{c}{ Peningkatan/Penurunan } \\
\cline { 3 - 4 }$(\mathrm{Rp})$ & Jumlah $(\mathrm{Rp})$ & $\%$ \\
\hline 2010 & $1,349,298,744$ & -- & \\
2011 & $1,540,007,862$ & $190,709,117$ & 14.13 \\
2012 & $1,686,970,889$ & $146,963,027$ & 9.54 \\
2013 & $1,866,601,299$ & $179,630,410$ & 10.65 \\
2014 & $2,155,864,366$ & $289,263,066$ & 15.50 \\
\hline
\end{tabular}

Sumber: data diolah, 2016

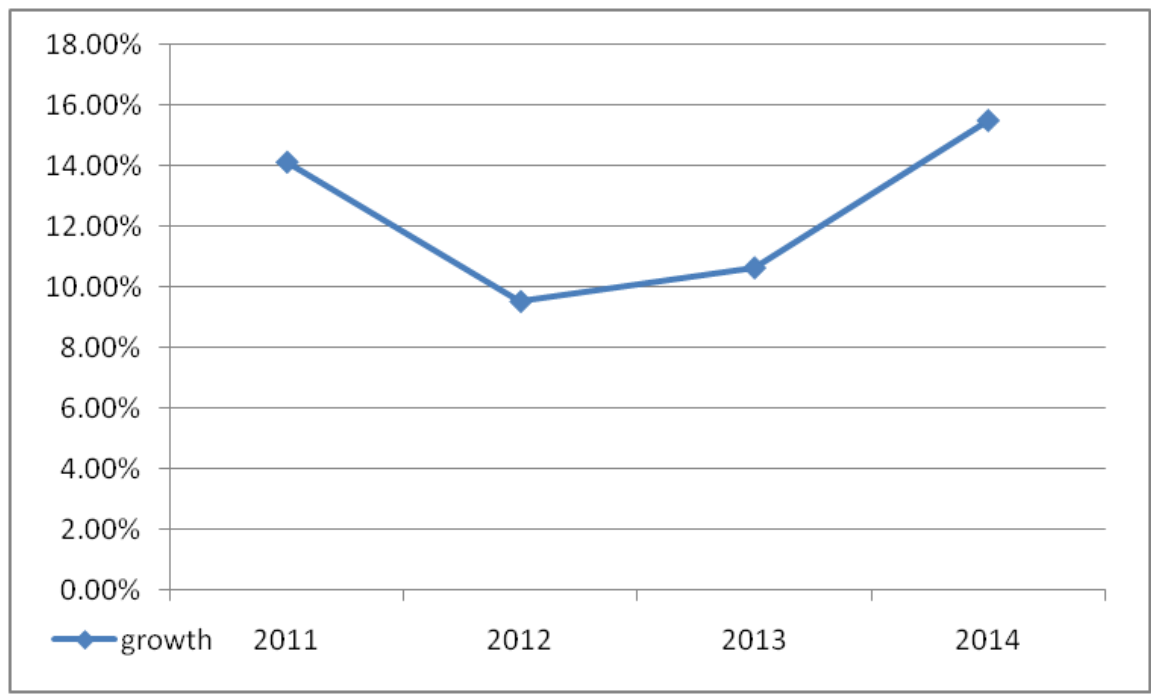

Sumber: data diolah, 2016

Gambar 2. Dinamika Modal Kerja Koperasi Konstranda Batan 2010-2014

Tabel 2 dan Gambar 2 menunjukkan bahwa persentase pertumbuhan modal kerja yang dimiliki oleh Koperasi Kostandra mengalami fluktuasi pada tahun 2011 sampai dengan 2014. Penurunan persentase modal kerja yang dimiliki sebesar $14,13 \%$ pada tahun 2011 turun sebesar 4,59\% pada tahun 2012 menjadi 9,54\% .

Menurut hasil wawancara dengan pengurus koperasi, hal ini disebabkan oleh lemahnya pendapatan pada bidang usaha pengadaan barang dan jasa, pada tahun ini pendapatan yang diperoleh mengalami penurunan yang diakibatkan berkurangnya jumlah permintaan serta lemahnya sistem yang dimiliki Koperasi Kostandra untuk mengambil proyek perusahaan dalam pengadaan barang dan jasa. Penyebab lemahnya sistem yang dimiliki adalah karena Koperasi Kostandra kekurangan sumber daya manusia (SDM) sehingga belum memiliki tim khusus untuk 
menangani proyek dalam jumlah besar, karena proyek pengadaan barang yang dibutuhkan pada Badan Tenaga Nuklir Nasional (BATAN) dengan jumlah nominal lebih dari Rp.200.000.000,(dua ratus juta rupiah) akan dilelang oleh perusahaan sehingga Koperasi Kostandra perlu memiliki sistem dan sumber daya manusia (SDM) yang memadai.

Pada tahun berikutnya, penerimaan dari bidang usaha pengadaan barang dan jasa semakin meningkat walaupun dalam jumlah kecil sehingga persentase pertumbuhan modal kerja Koperasi Kostandra semakin baik dan mengalami peningkatan sebesar $1,11 \%$ pada tahun 2013 menjadi 10,65\%. Pada tahun 2014 bidang usaha pengadaan barang dan jasa men-dapatkan penerimaan yang tinggi sehingga persentase pertumbuhan modal kerja berada pada posisi $15,50 \%$ dan merupakan titik tertinggi per-tumbuhan persentase dari 5 tahun terakhir, dengan rata-rata persentase pertumbuhan selama 5 (lima) tahun sebesar 12,45\%.

Verifikasi terhadap model regresi penduga dilakukan dengan mengkorelasikan modal kerja dengan likuditas yang hasilnya tampak dalam ilustrasi grafis pada Gambar 4. Berdasarkan tabel di atas dan hasil penelitian yang dilakukan, besarnya hubungan modal kerja yang ditunjukkan pada huruf $\mathrm{R}$ sebesar 0,830 berada diantara interval koefisien 0,80 hingga 1,00 yang menjelaskan bahwa terdapat korelasi atau tingkat hubungan sangat kuat antara modal kerja dengan likuiditas pada Koperasi Kostandra Batan.

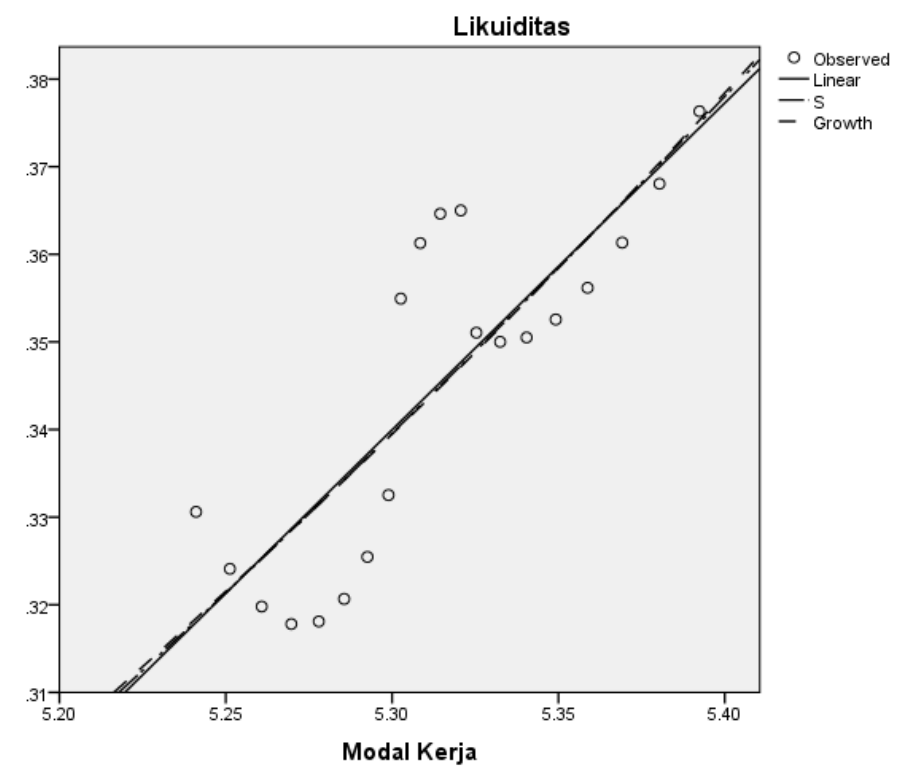

Sumber: data diolah, 2016

Gambar 3. Uji Linearitas Model 
Ekonomika-Bisnis,Vol. 7 No. 1 Bulan Januari Tahun 2016 Hal 55-66

\begin{tabular}{lrrrr}
\hline \multicolumn{4}{c}{ Tabel 3. Hasil Pendugaan Model Regresi } & \\
\hline \multicolumn{1}{c}{ Variabel } & Koefisien & $\begin{array}{c}\text { Simpangan } \\
\text { Baku }\end{array}$ & t hitung & \multicolumn{1}{c}{ Sig } \\
\hline Kostan & -1.637 & 0.314 & -5.218 & 0.000 \\
Modal Kerja & 0.373 & 0.059 & 6.318 & 0.000 \\
$\mathrm{r}$ & 0.830 & & & \\
\hline $\mathrm{r}^{2}$ & 0.689 & & & \\
$\mathrm{~T}$ tabel & 2.100922 & & & \\
\hline
\end{tabular}

Sumber: data diolah, 2016

Hasil pendugaan pengaruh
modal kerja terhadap likuditas sebagaimana tampak dalam tabel 3. Berdasarkan hasil penelitian yang telah dilakukan, didapat hasil korelasi yang menunjukkan bahwa modal kerja dan likuiditas memiliki hubungan positif sebesar 0,830, hal ini dapat menjelaskan bahwa terdapat hubungan yang sangat kuat antara modal kerja dan likuiditas pada Koperasi Kostandra, hasi tersebut didukung dengan nilai koefisien determinasi sebesar 0,689 yang menjelaskan bahwa 68,9\% likuiditas mampu dipengaruhi oleh modal kerja dan sisanya akan dipengaruhi oleh variabel lain.

Di samping itu perubahan modal kerja sebesar $1 \%$ diketahui akan menaikkan tingkat likuiditas sebesar $37,3 \%$, hal ini ditunjukkan pada output koefisien yang menghasilkan nilai konstan sebesar -1,637 dan modal kerja sebesar 0,373. Dengan demikian pada penelitian ini dapat diketahui jika modal kerja yang dimiliki berpengaruh terhadap tingkat likuiditas pada Koperasi Kostandra.

Modal kerja yang dimiliki oleh setiap badan usaha, termasuk koperasi, menjadi bagian yang perlu di-perhatikan oleh pengurus koperasi. Hal ini disebabkan modal kerja yang dimiliki akan digunakan untuk membiayai operasional kegiatan usaha.
Sebagai ilustrasi, pada koperasi terdapat unit usaha penjualan (toko). Pada tahap awal, koperasi hanya mampu menyediakan air mineral sebanyak 100 galon per tahun, jika modal kerja bertambah pada periode berikutnya, hal ini berarti koperasi mampu meningkatkan jumlah persediaan air mineral lebih dari 100 galon sehingga hasil penjualan air mineral akan menambah jumlah kas

koperasi, dimana kas adalah komponen pada aktiva lancar.

Sebagaimana termaktub dalam konsep likuditas, likuiditas adalah ukuran yang mengukur kemampuan entitas usaha dalam membayar kewajiban jangka pendeknya. Dalam formula matematika, rasio lancar (current ratio) misalnya. Rasio ini membandingkan besaran antara aktiva lancar dengan hutang lancar.

Dalam struktur laporan keuangan koperasi secara umum, komponen aktiva lancar terdiri dari: kas, bank, surat berharga, piutang usaha, piutang pinjaman anggota, piutang pinjaman non-anggota, penyisihan piutang tak tertagih, persediaan, biaya dibayar di muka, dan pendapatan yang masih harus diterima.

Melihat komponen tersebut, kenaikan pada aktiva lancar akan mempengaruhi persentase tingkat likuiditas pada periode tersebut. Common 
Working Capital dan Likuiditas...(Leonardo Jhones Pattipeilohy, Pitri Yandri)

sense ini mengonfirmasi bahwa modal kerja memiliki pengaruh terhadap tingkat likuiditas pada Koperasi Kostandra. Hasil penelitian ini kemudian mengonfirmasi penelitian terdahulu yang telah dilakukan oleh Nizam (2009) dan Widiastuti (2011).

\section{Penutup}

Modal kerja memiliki pengaruh positif signifikan dimana hal tersebut tergambar pada nilai korelasi sebesar 0.828 yang menunjukkan terdapat pegaruh yang kuat antara modal kerja dengan likuiditas dan hasil perhitungan koefisien determinasi sebesar 0.686 yang menggambarkan keeratan hubungan antara variabel $\mathrm{X}$ (modal kerja) dan variabel $\mathrm{Y}$ (likuiditas) dimana $68 \%$ dari likuiditas dipengaruhi oleh modal kerja dan sisanya sebesar $32 \%$ dipengaruhi oleh variabel-variabel lain. Disamping itu perubahan modal kerja sebesar $1 \%$ diketahui akan menaikkan tingkat likuiditas sebesar $37,3 \%$, hal ini ditunjukkan pada output koefisien yang menghasilkan nilai konstan sebesar -1,637 dan modal kerja sebesar 0,373.

\section{DAFTAR PUSTAKA}

Kasmir. 2015. Analisis Laporan Keuangan. PT Raja Grafindo Persada: Jakarta.

Quayyum, S.T. 2011, Effect of Working Capital Management and Liquidity: Evidence from the Cement Industry of Bangladesh, Journal of Business and Technology (Dhaka), Vol. VI., Number-01, January-June, 2011: 37-47.

2012, Relationship between Working Capital Management and Profitability in Context of Manufacturing Industries in Bangladesh, International Journal of Business and Management, Vol. 7, No. 1, January 2012: 58-69.

Nopiana, Y., Herawati N.Y. dan Sulindawati., N.L.G. 2015, Pengaruh Tingkat Perputaran Modal Kerja, Perputaran Kas, Perputaran Piutang, Pertumbuhan Jumlah Nasabah, dan Jumlah Karyawan terhadap Profitabilitas Koperasi Simpan Pinjam (KSP) di Kabupaten Buleleng, e-Journal S1 Akuntansi Universitas Pendidikan Ganesha, Vol. 3, No. 1 Tahun 2015: 1-12.

Hadinata, N.P.T. dan Wirawati, N.GP. 2016, Pengaruh Tingkat Perputaran Kas, Perputaran Piutang, Likuditas dan Pertumbuhan Koperasi pada Rentabilitas Ekonomi, e-Jurnal Akuntansi Universitas Udayana, 14.2 Februari (2016): 1034-1063.

Makori, DM. dan Jagongo, A.J. 2013, Working Capital Management and Firm Profitability: Empirical Evidence from Manufacturing and Construction Firms Listed on Nairobi Securities Exchange, Kenya, International Journal of Accounting and Taxation, No. 1, No. 1, December 2013: 1-14.

Widiastuti, R,. 2011. Analisis Pengaruh Modal Kerja Terhadap Likuiditas PT. Ecom Internasional Jakarta. Jakarta: STIE Ahmad Dahlan Jakarta.

Nizam, T.M.S., 2009. Pengaruh Sumber dan Penggunaan Modal 
Ekonomika-Bisnis, Vol. 7 No. 1 Bulan Januari Tahun 2016 Hal 55-66

kerja Terhadap Likuiditas dan

Rentabilitas pada PT Irian

Marine Product Development

Jakarta. Jakarta: STIE Ahmad

Dahlan Jakarta.

Juanda, B,. 2009. Ekonometrika

Permodelan dan Pendugaan.

Bogor: IPB Press. 